\title{
微小流体光学に向けたチップ内組み込みレーザーの研究
}

\author{
鍬光 浩太 ${ }^{1}$ ，吉岡 宏晃 ${ }^{1}$, 片岡 周作 ${ }^{1}$, 鳴石 奈穂子 ${ }^{2}$, 田中 喜秀 ${ }^{2}$, 興 雄司 ${ }^{1}$ \\ ${ }^{1}$ 九州大学大学院 システム情報科学研究院 (广819-0395 福岡市西区元岡744) \\ 2産業技術総合研究所 健康工学研究部門 ( $=563-8577$ 大阪府池田市緑丘1-8-31)
}

\section{Development of Integratable Laser for Optofluidic Chip}

\author{
Kota KUWAMITSU, ${ }^{1}$ Hiroaki YOSHIOKA, ${ }^{1}$ Shusaku KATAOKA, \\ Nahoko NARUISHI, ${ }^{2}$ Yoshihide TANAKA, ${ }^{2}$ and Yuji OKI ${ }^{1}$ \\ ${ }^{1}$ Faculty of Information Science and Electrical Engineering, Kyushu University, 744 Motooka, Nishi-ku, Fukuoka 819-0395 \\ ${ }^{2}$ Advanced Institute Science and Technology (AIST), 1-8-31 Midorigaoka, Ikeda, Osaka 563-8577
}

(Received August 22, 2012)

\begin{abstract}
Integratable and disposable solid-state dye lasers with a distributed feedback waveguide structure were studied. We fabricated the coupling of a methacrylate copolymer waveguide and similar substrate and demonstrated primitive fluorescence detection. We also developed laser integration on a beam-shaper with an optical fiber for fluidic chips of polydimethylsiloxane.
\end{abstract}

Key Words: Optofuidic, Microflowcytometry, Dye laser, Waveguide, PDMS

1. はじめに

有機色素レーザーはレーザーの初期より研究されてき たレーザーである。有機蛍光分子は，分子設計により 様々な波長特性の設計が可能で，高いスペクトル輝度と 誘導放出断面積を持つ一方, 短い蛍光寿命に起因する高 い励起光強度と光化学反応などによる分子構造の変性に よる劣化が不可避である。媒質が液体であれば, 循環系 や成型の為のセルなどが必要で総じて複雑であるもの の, 劣化問題はさほど問題にならないが, 有機溶媒の可 燃性やコンタミネーションの問題から一般での応用は難 しい，そこで，固体レーザーが主要なレーザー装置とな る一方で, 可燃性・污染問題解決のアプローチの一つと して，有機分子を固体レーザーとして発振させる研究も これまで行われてきた ${ }^{1-4)}$.

我々は，固体色素レーザーの利点として液相プロセス が可能な高分子マトリクスに着目し，有機導波路構造を 印刷的技術で構築するプリンタブル導波型レーザーの研 究を行ってきた 。特に微小アプリケーションのチップ 内に直接レーザーを構築することで, 励起光としての固 定波長レーザー光をアプリケーションに必要な波長に変 換して必要に応じて近接照射できる。将来的に有機LD の発振はこうしたデバイスをさらに発展させることが予 測できるが, 光励起レーザーであっても現実的な出力強 度で, 調整・メンテナンス不要な使い捨て光源が可能と なる点で興味深い。本稿では, optofluidicチップの一例 としてマイクロフローサイトメトリーチップを対象の一
つに，有機固体レーザーを組み込む上でのポイントを研 究した結果について報告する。

2. レーザー作製プロセスとアラインメント

Fig. 1にプリンタブルプロセスを示す。これまで高分 解能ディスペンサー（武蔵エンジニアリング，ML5000XII) と細線描画用SUSニードル(岩下エンジニアリ ング, PRN0.06, 内径0.06 mm) を組み合わせたロボット 描画装置を利用して，断面幅60 $\mu \mathrm{m} \sim 120 \mu \mathrm{m}$ の導波路直 接描画を行ってきた。我々が開発した無溶媒プレポリ マーペン描画法(以降ペン描画と呼称)では, 高粘度状態 のポリメタクリル酸メチル(PMMA) と未重合のメタク

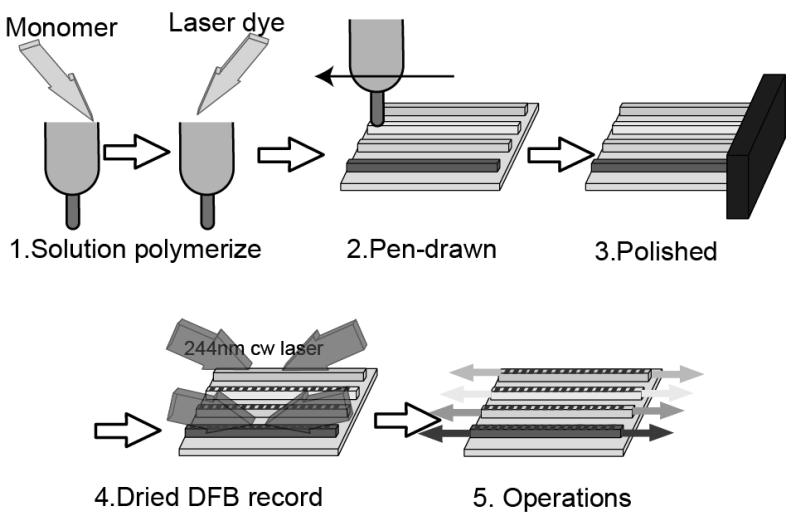

Fig. 1 Process for printable waveguide of DFB laser array. 
リル酸メチル (MMA)の混合状態の「プレポリマー」を作 製し，これに色素を混合してペン描画に利用する。描画 後のポストアニール $\left(72^{\circ} \mathrm{C}, 120 \mathrm{~min}\right) に よ り \mathrm{MMA}$ を蒸発 あるいは重合させて固化を完了し，その後回折格子を記 録することで分布帰還構造 (DFB) を作製する ${ }^{6)}$. 導波路 は縦シングル横マルチモードにすることで出力を増やす 構成になっており, 膜厚は3〜 $5 \mu \mathrm{m}$ となるが, 膜厚が一 定でないとDFBの発振スペクトル幅が拡がったりASEな どによる広帯域な成分が増大したりする。

微小ストライプの描画後固化において，低粘度溶液は マランゴニ対流が支配的になり，断面プロファイルがM 字型に, 高粘度溶液ではの字型となる。しかし, ペン描 画法では，導波路の屈折率制御にも利用するメタクリル 酸 2 -ヒドロキシエチル (HEMA) との共重合プレポリマー のブレンド比率を調整することで，両者の中間点の台形 型の断面プロファイルを得ることが可能である。この場 合, 導波路の中央部分には厚さの変化がないフラット トップとなり，良好なレーザースペクトルを得ることが できる.

マイクロフローサイトメトリーに扮ける流路の断面寸 法は60〜100 $\mu \mathrm{m}$ 程度が一般的で，ここにレーザーを近 接照射する際にはビーム幅はこれらよりも細い30 $\mu \mathrm{m}$ 以 内に抑えるのが理想的である。.Fig. 3に，レーザー導波 路を組み込んで直接励起光を流路内に結合させる時，考 え得るアラインメントを図示する。流路を維持するため

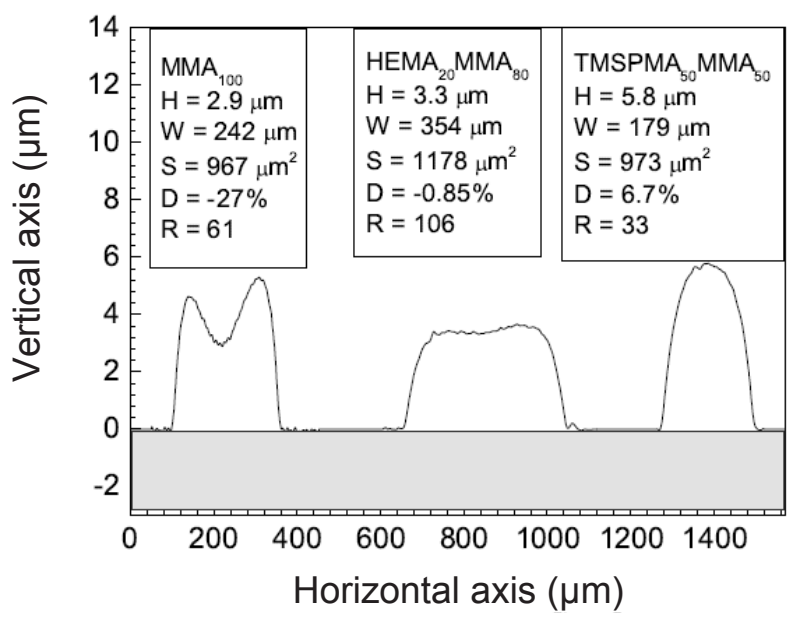

Fig. 2 Measured waveguide cross section profiles in various copolymer composition.

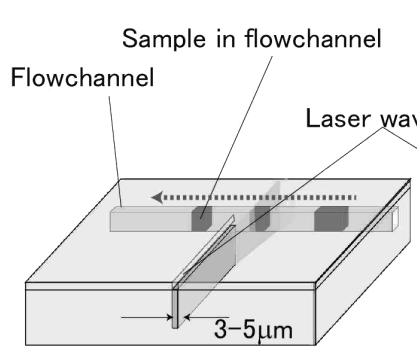

(a) Horizontal single mode

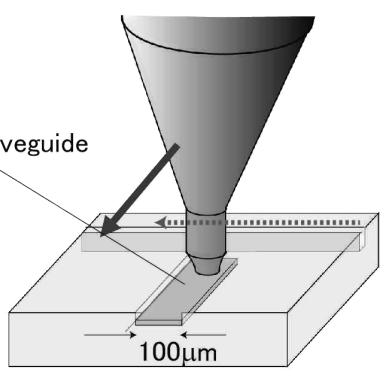

(b) Vertical single mode
Fig. 3 Laser alignment for microflowchannel coupling. Single mode confinement direction is parallel (left) and perpendicular (right) to the flow direction.
にポリマー素材では隔壁の厚さが数 $10 \mu \mathrm{m}$ 以上必要であ り，そのため，レーザー出射部から50 $\mu \mathrm{m}$ 程度伝搬した ビームが流路と鎖交した時のビーム幅が分解能を決定す ることになる。よって，レーザー導波路の組み込み向き はシングルモードの閉じ込め方向を流路の流れに平行に 配置する (a)と，垂直に配置する(b)で異なる。

配置(a)ではシングルモード閉じ込め方向のビーム広 がりが大きくなる。屈折率構造が対称であるシングル モード導波路の基本 $\mathrm{TE}_{0}$ モードであれば，ガウスビーム 理論計算でビーム広がりを近似でき，ビーム出射位置の フィールド幅を5〜 7 $\mu \mathrm{m}$ にしないと条件を満足できない 事が予測できる。しかし，波長600 nmでコアを5 $\mu \mathrm{m}$ と するとシングルモード条件を満足できない，また，レー ザーを横励起する場合，励起光をシート状に成形・入射 する方向は流路に沿った方向となり，励起光光学系を チップに埋め込まないと励起がしにくい.

配置(b)は作製が容易である一方，マルチモード閉じ 込めの方向が流路内での分解能を決めるため，導波路の

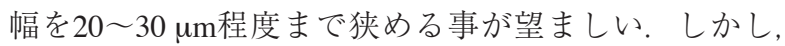
PRN0.06ノズル内径は0.06 mmであり，描画幅60１00 $\mu \mathrm{m}$ では分解能も上がらない.

\section{PMMAを利用したプロトタイプチップ}

\section{1 作製手順}

まずはPMMAのプロセスのみを利用した単純な流路 チップヘの組み込みを行った。作製の容易な配置 (b)を ここでは採用した。既にエキシマーレーザーのマスク 露光によるレジストを用いないプロセスを用い，チップ の作製とレーザーの組み込みを行ったプロセスをFig. 4

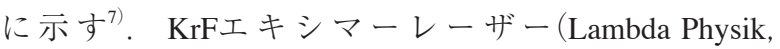
COMPeX 110) で石英マスクを通してPMMA基板を露光 し, ウエットエッチングで深50 $\mu \mathrm{m}$ のレーザー用溝と, 深さ90 $\mu \mathrm{m}$ の流路溝を作製する。その後, ペン描画によ り，クラッド層を描画し，その上にレーザー層を作製し た。レーザー層は色素の添加により屈折率が0.004程上 昇することを利用して導波路を構成している。レーザー は右下のように流路の高さから見て中央に配置されてい

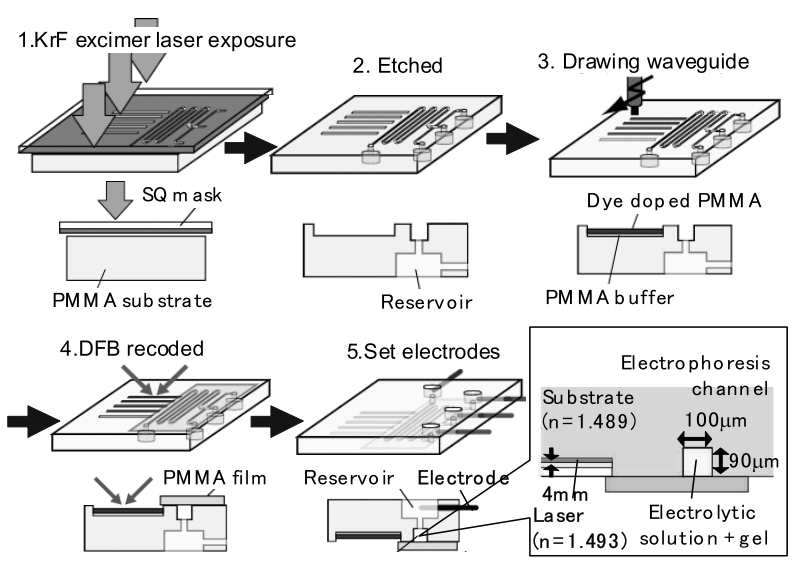

Fig. 4 Process of PMMA flowchannel and laser waveguide. 
る。描画で作製したチップでは導波路端でレーザーが乱 されるため, この部分には屈折率をそろえたp (HEMA: MMA）を埋めることでビーム散乱を抑えた。 DFBを作製 後, 電極をリザーバーに取り付け, 電解質とゲルを流路 に詰めた

Fig. 5は作製したチップの外観である。流路設計は屈 曲させてチャンネル長を $95 \mathrm{~mm}$ まで伸ばし, 流路の最後 の部分には色素として, rhodamine590, pyrromethene567, LDS722，LDS798の4種類の色素をドープしたレーザー を組み达んた。それぞれの発振波長は590，600，580，

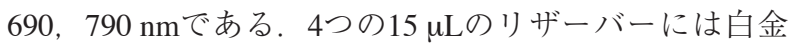
電極をセットし， R1にNileblue690等の色素を注入後, リザーバーR1-R2間に $40 \mathrm{~V} / \mathrm{cm}$ の電圧をかけて十字点ま で導入後, R3-R4に70 V/cmをかけてFig. 5下のように電 気泳動で試料を切り出した.

\section{2 レーザー特性評価と電気泳動実験}

Fig. 6は一つのレーザーのスペクトルと, それによる 蛍光のスペクトルである.レーザー光は600 nmに同調 してあるが, 励起光である532 nmも観測されている. ノイズとなるのは蛍光の波長域700 nm付近まで伸びて

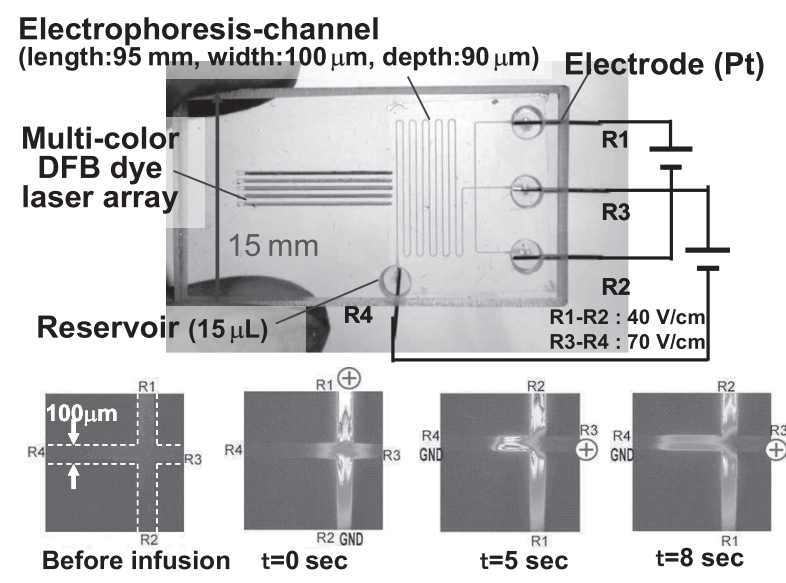

Fig. 5 Photo image of prototype of PMMA flowcytometry chip with laser (above) and sample infusion at cross point (below).

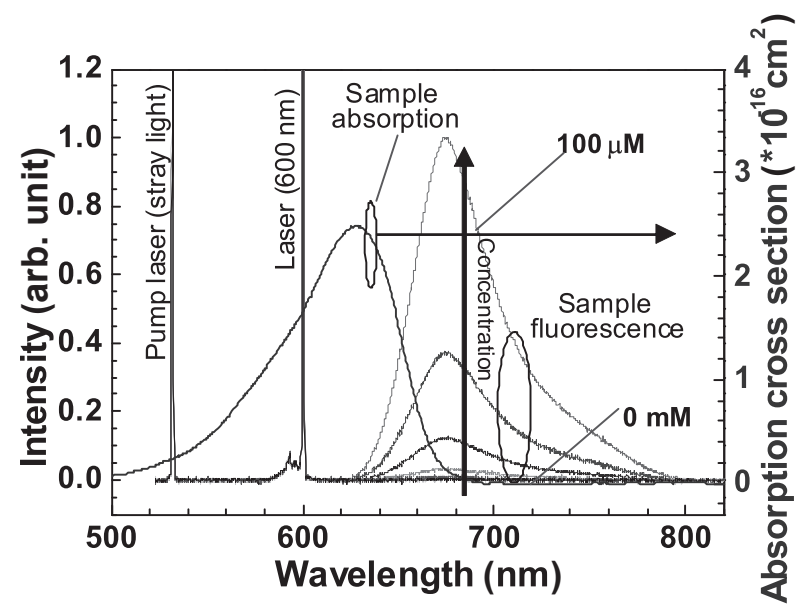

Fig. 6 Spectra of DFB dye laser, pumping laser stray light, and fluorescence from samples of which concentration is $0 \sim 0.1 \mathrm{mM}$.
いるレーザー導波路からの色素蛍光 $(\mathrm{ASE})$ であるが，色 素濃度の調整とDFB構造を強めに作製する事で, レー ザーピーク強度の $10^{-4}$ 程度まで抑える事に成功してい る。濃度を変えて計測した結果, 背景光レベルが $200 \mathrm{nM}$ 相当であり，背景光の除去の工夫がまだ必要で あるものの，初めて組み込みレーザーによるLIF (Laser induced fluorescence) 計測に成功した.

最後に, 切り出し後にレーザー $(600 \mathrm{~nm})$ を励起しな がら流路中を電気泳動する試料からの蛍光を検出した。

Fig. 7にその結果を示す。泳動開始から4150秒後をピー クとして，時間パルス幅が473秒となり，理論段数は

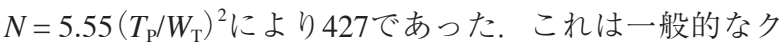
ロマトグラフィより劣るが, 屈曲の多い流路を利用した のが理由であると考えられ，また，レーザーのアライン メントが(b) 型でレーザー幅も $100 \mu \mathrm{m}$ と広いことも原因 の一つであると考えられる。

こうした結果から, Fig. 3 (b) の構成ではなく構成 (a) でのレーザーの組み込みを考え，同時に実際のマイクロ フローサイトメトリーチップに近い設計での実験を行う ため，作製組み达み対象をPDMS，配置(a)を採用して 研究行う必要性が明らかになった。

\section{4. 励起光学系集積レーザーのPDMS組込み}

本節では, 励起光学系の面内組み込みと配置 (a) 採用 に伴う問題点の洗い出しを目的に研究を行った。前述の 実験ではレンズを組み合わせた光学系で励起光をシート 状に集光する光学系を利用し，チップ上方から入射して いたが，配置 (a)では光学系をPDMSチップの厚さ1〜 $2 \mathrm{~mm}$ の空間に埋め込む必要がある。ペン描画を最大限 に利用した作製法で組み达みアラインメントを調査でき る組み込みレーザーを作製した8).

\section{1 作製手順及び組み达み手順}

Fig. 8に設計した組み込み型集積レーザーの概念図を 示す. PMMAフィルム $(125 \mu \mathrm{m}$ 厚 $)$ を用い, 光ファイバ をこれに結合してビームを一方向にのみ広げるビーム成

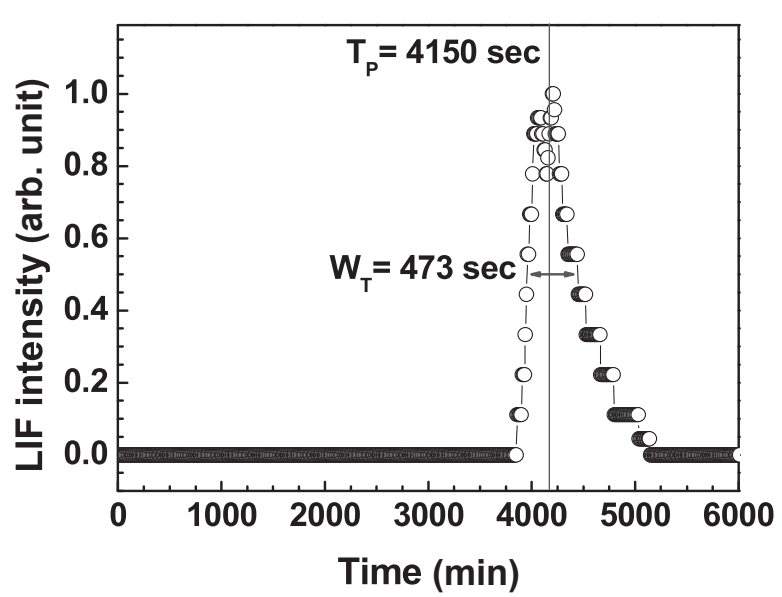

Fig. 7 Temporal modification of laser induced fluorescence from fabricated chip. Sample is nileblue690 and laser dye is rhodamine590. 


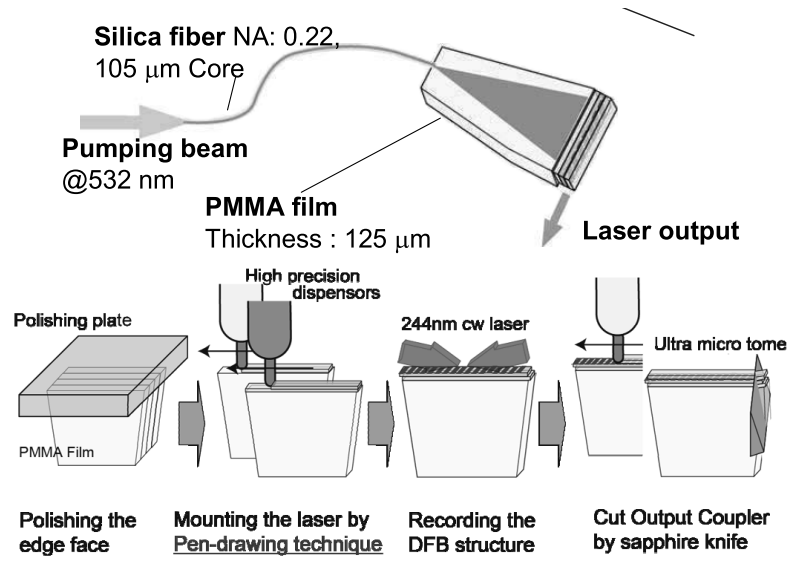

Fig. 8 Schematic of laser on organic-film beam shaper and its fabrication process.

型フィルムを発案した. フィルムの端面を光学研磨し, この上にペン描画法により屈折率差を小さく設計した三 層を積層描画した。 なお, コア膜厚を安定させるため,

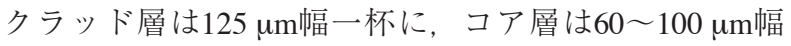
に抑え，2層描画後にDFB構造を記録後，第3層をコート

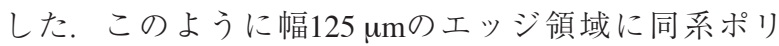
マーを3層積層することは従来のスピンコート等では不 可能であり，ペン描画により初めて可能となったと言え る。ポストアニール後, ウルトラミクロトーム (Sorvall 社, UltraMicrotome MT-1) を用いてレーザーの出射面を 作製した。各導波路の屈折率制御は共重合ポリマー $\mathrm{p}\left(\mathrm{MMA}_{1-x}: \mathrm{HEMA}_{x}\right)$ で主に行い, 屈折率の校正はプリズ ムカプラー(メトリコン社, Model2010)により波長 $633 \mathrm{~nm}$ に対する実測值を元に行なった.

Fig. 9はPDMSチップへの組み込み手順を示す。PDMS チップを作製するモールドマスターとしてはSU-8 3035 (マイクロケム)を用いて Siウエハー上に作製し, 流路断 面サイズは60 $\mu \mathrm{m} \square$ と, 屈曲のないストレートのパ ターンを用いた。これに作製したレーザー付きビーム成 型フィルムとクリーブした石英光ファイバ(125 $\mu \mathrm{m}$ 径,

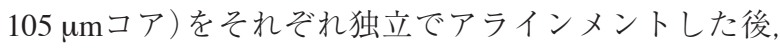
PDMSを接合部に投入してアラインメントを調整しつつ 固定を行なった。レーザー出射光が流路位置にある SU-8に照射するアラインメント調整を行い, レーザー 出射部と流路の距離は60〜70 $\mu \mathrm{m}$ に調整して固定した.

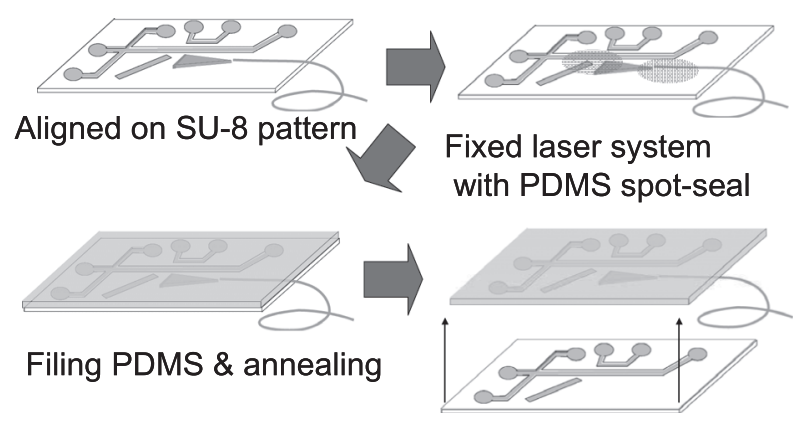

Lift off \& post annealing

Fig. 9 Integration procedure of laser and organic film beam shaper into PDMS flowcytometry chip.
固定後全域にPDMSを注入し，チップを完成させ，固化 後にモールドマスターからリフトオフしてPDMS薄膜で 蓋をしてチップとした。PDMSには室温硬化型高精細 PDMS (信越石英, SIM-360)を用いた。

作製例の写真をFig. 10に示す。写真中央にはrhodamine6Gを利用したDFBレーザーが埋め込まれており， レーザーへの励起光入射は光ファイバからビーム成型 フィルムを経由してチップ外への光の漏れが無いように 行われている。組み达まれたレーザーの長さは $5 \mathrm{~mm}$, 膜厚は $3 \mu \mathrm{m}$ でクラッドとの屈折率差は0.0015程度に設計 した. Fig. 10の左下はレーザー出力部とマイクロ流路の 結合部の顕微鏡写真であり，レーザーと流路の距離は $70 \mu \mathrm{m}$ とし，レーザー出力が流路と鎖交する様にアライ ンメントを調整している。レーザー導波路の屈折率設計 はコア1.495, クラッド1.493となるよう，共重合ポリ マーのHEMA添加率をそれぞれ $5 \%$ ，2.5\%とした。コア 厚は約 $3.5 \mu \mathrm{m}$ である。周囲のPDMSは屈折率が1.408で, これもビーム成型フィルムではクラッドとして機能す る.

Fig. 11にクラッドによるビーム広がりの抑制の結果を 示す。実測ではレーザーを無固化のPDMS中で動かし， 流路との距離を変えながら流路側壁の散乱光を顕微鏡

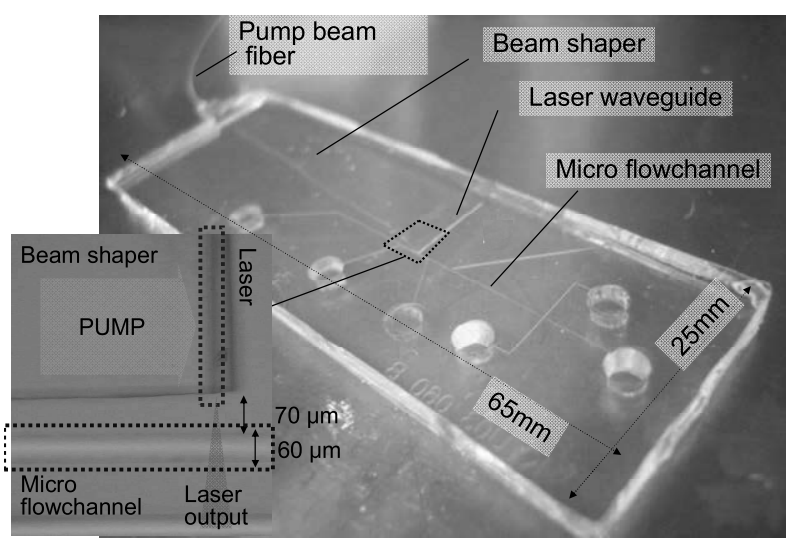

Fig. 10 Photoimage of PDMS chip with integrated laser waveguide and organic film beam shaper. Inset (left below) is the microscopic image of coupling point.

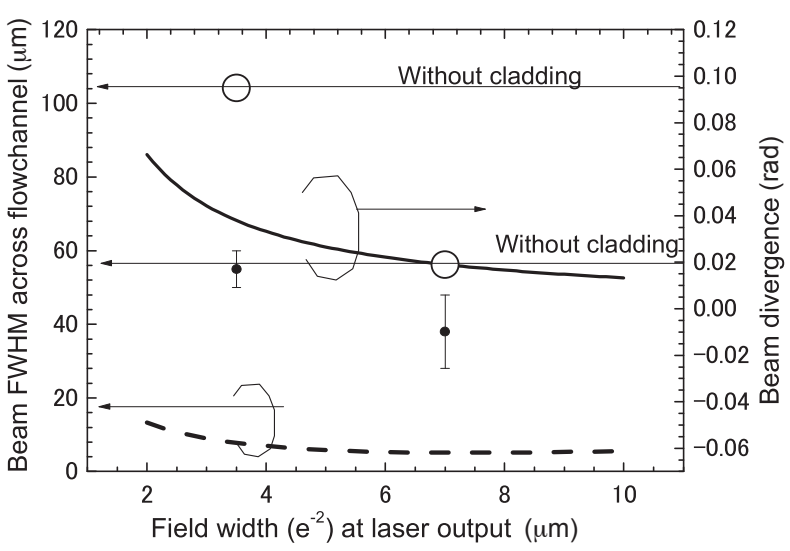

Fig. 11 Beam divergence and width across flow-channel. Solid line is numerical calculation and mark is experimental result. 
CCDカメラ (Nikon eclipse Ti) で観測し, 画像処理後ガウ シアンフィットしたビームプロファイルから半值幅を求 め, ビーム広がり角を求めた。 クラッドによる広がり抑 制層がない場合，コア層厚3.5 umに対して広がりは $95 \mathrm{mrad}$ あった。対して，クラッディングを施した レーザーは10〜19 mradが観測された．Fig. 11に計算に よるガウスビーム広がりを示すが，計測結果（○マーク） から出射時のビームフィールド全幅 $\left(e^{-2}\right)$ は7 $\mu \mathrm{m}$ と見積

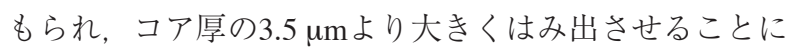
成功している。対して, 広がり防止がない場合, 非対称 導波路の為か広がりが大きく $3.5 \mu \mathrm{m}$ フィールド幅の計算 結果とも合致しない。一方でビーム絶対幅の観測結果 (○マーク)は共に同様の理論計算(破線)より20 $\mu \mathrm{m}$ 近く 大きな值が得られている。これは観測系の分解能の問題 などが考えられるが, ビーム広がりを抑える事で流路に 鎖交するビーム幅を，ほぼ30 $\mu \mathrm{m}$ 一定にできた。

コア・クラッドの屈折率差を 0.001 とする場合, コア にドープされた色素に起因する屈折率異常分散が屈折率 差に与える影響を無視できない．色素添加による屈折率 変化はこれまでも考慮して設計を行ってきたが, 今回, 色素をpyrromethene567に変更して発振波長を570 nm と 短い領域に設定した際シシングルモード設計されていた にもかかわらず導波モードが2つ確認され，設計通りの 結果を得ることができなかった。屈折率の異常分散を吸 収バンドと誘導放出バンドをローレンツプロファイルで フィッティングして計算すると, pyrromethene色素分 子の密度 $8 \mathrm{mM}$ で屈折率変化量の概算は発振波長域で $0.001 \sim 0.002$ 程度と見積もられ，励起の反転分布の状況 での変化も無視できない事が分かった。このため, 屈折 率設計には色素添加による正常分散屈折率の増減だけで なく異常分散や励起条件までも考慮する必要があり, 実 験による発振特性を確認しながら屈折率設計を行なう必 要性も明らかとなった

蛍光測定光源用レーザーとしてもう一つ重要な条件と して, 長波長側の背景光成分の低減がある. 励起された 蛍光色素の発光波長と同じ波長域のレーザー光成分は観 測用フィルタでカットできないためDFBレーザーにおい てどの程度抑えるかが重要である。発振波長よりも $10 \mathrm{~nm}$ 長波長側の線強度は通常の色素レーザーでは $10^{-3}$ 程度の抑制率であるが, 色素濃度を下げるあるいは色素 の蛍光波長の長波長域での発振を用いることにより, $2 \times 10^{-4}$ 程度まで低減することができている

最後に, 色素レーザーと流路間のアラインメントを行 なうため, 流路に流れる色素から蛍光を観測している様 子をFig. 12に示す。右の流路は校正用の流路で, 左は測 定用である。標識色素Cy $5^{\circledR}$ とスペクトル特性が類似し ている色素として，1,1,3,3,3',3'hexamethylindodicarbocyanine iodide (HIDCI) 水溶液を使用して測定を行った。校 正用流路での蛍光幅は38 $\mu \mathrm{m}$ 程度となっている。

このようにレーザー組み込みチップにおける問題点を

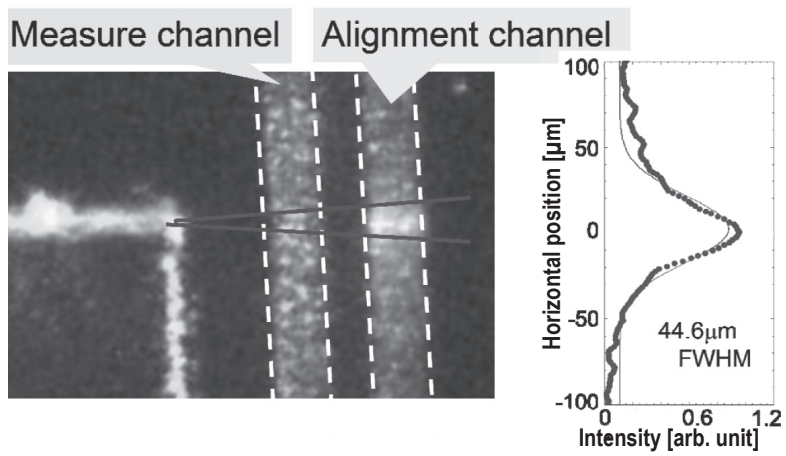

Fig. 12 HIDCI fluorescence image and beam intensity profile.

一つ一つ解決し, 蛍光検出実験を行なう段階まで現在研 究は進んでいる。一方で, 問題点も明らかになってお り，良好な蛍光信号を得る事ができる歩留まりや作製手 順の煩雑さから, 次のステップとしてPDMSチップに直 接描画する手法への回帰も検討中である。現在 $20 \mu \mathrm{m}$ 細 線描画に部分的に成功しているため構成 (a)によるアラ インメントでもPDMS内組み达みで分解能をある程度確 保できる見通しがある。

\section{5. まとめ}

全PMMAのモノリシックなマイクロ流路チップへの レーザーの組み込みプロトタイプを行い, レーザー蛍光 実験を行った。さらにレーザーのアラインメントや構築 向きの検討を行い, PDMSチップへの複合有機材料・光 ファイバ導光を利用したチップ組み込みも行い, レー ザー組み込みにおけるアラインメントやビーム広がりの 最適化設計の検討と実験による問題確認を行った。今後 はアラインメントの問題を解決し，具体的な信号検出実 験に進むために，作製プロセスの改善と実験を行ってい $<$.

\section{参考文献}

1) F. Duarte: Opt. Commun. 117 (1995) 480.

2) A. Maslyukov, S. Sokolov, M. Kaivola, K. Nyholm, and S. Popov: Appl. Opt. 34 (1995) 1516.

3) A. Costela, I. Garcia-Moreno, R. Sastre, D.W. Coutts, and C. Webb: Appl. Phys. Lett. 79 (2001) 452.

4) Y. Oki, S. Miyamoto, M. Tanaka, D. Zuo, and M. Maeda: Optics Commun. 214 (2002) 277.

5) Y. Yang, R. Goto, S. Omi, K. Yamashita, H. Watanabe, M. Miyazaki, and Y. Oki: Opt. Express 18 (2010) 22080.

6) Y. Oki, T. Yoshiura, Y. Chisaki, and M. Maeda: Appl. Opt. 41 (2002) 5030.

7) S. Kataoka, N. Kamogawa, M. Tanaka, H. Watanabe, K. Yamashita, M. Miyazaki, S. Kuhara, and Y. Oki: Tech. Digest of The 6th Asia Pacific Laser Symposium (2008) 53.

8) K. Kuwamitsu, H. Yoshioka, R. Goto, H. Watanabe, N. Naruishi, Y. Tanaka, and Y. Oki: Tech. Digest of IQEC/CLEO Pacific Rim (2011) 378 . 